\title{
Theoretical and Experimental Analysis of the Cracking Moment in Reinforced Concrete Footing Supported in Granular Soil
}

\author{
Rodrigo Gregorio Hernandez Ávila*, Jhon Jairo Feria Díaz and Fernando Jove Wilches \\ Department of Civil Engineering, University of Sucre, Carrera. 28, No. 5-267, Puerta Roja, Sincelejo, Colombia; \\ rodrigo.hernandez@unisucre.edu.co, jhon.feria@unisucre.edu.co,fejowi@yahoo.es
}

\begin{abstract}
Objective: To analyze flexural behavior of insulated footings supported on granular material and subject to low loads. Methods/Analysis: Experimental program included tests on 30 square reinforced concrete footings, $450 \mathrm{~mm}$ in length and reinforced with $6.3 \mathrm{~mm}$ bars. Experimental results were compared with theoretical results, according to the ACI 31814 Code. Findings: Results showed an average relationship between moment of experimental and theoretical cracking, in a range from 1.03 to 1.55. It was discovered that the value of rupture modulus recommended by the code was conservative. Application: It is required to continue with a more detailed study to establish influence of steel amount on the magnitude of the cracking moment of isolated footings.
\end{abstract}

Keywords: Cracking Moment, Flexural Tensile Strength, Modulus of Rupture, Spread Footing

\section{Introduction}

Isolated footings are among the types of surface foundation elements. They are characterized for transferring load coming from a column to the foundation ground through its base. They are probably the most common, simple and economical among distinct types of footing used for structures ${ }^{1}$. Experimentation on foundation elements is a very important research field for civil engineering, since it has allowed modifications to the specifications set out in the distinctive design codes over time. Recently, different researches in structural design field of isolated footings have been focused on the study of punching shear strength ${ }^{2}$.

Procedure for designing footings, as for other reinforced concrete elements, is based on the way they can fail ${ }^{3}$. Research has shown that distinct types of structural behavior may occur, before reaching the maximum footing resistance. The possible ways in which an isolated footing can fail are ${ }^{3,4}$ :

Flexion (Fragile failure): For elements with low steel amounts. Its capacity resistant to bending is less than the calculated for a simple concrete element,

Flexion (Ductile failure): For elements with amounts that allow the steel to reach its creep,

Flexion (Compression failure): Elements with considerable steel amounts, with excess concrete compression resistance,

Cutting: Elements with sufficient amounts to support adequate anchoring and bending length. Failure can occur by shear in one direction or by punching, and 
Adhesion: Elements with sufficient amounts to withstand insufficient bending and anchor length. The fault takes the form of sliding between steel and concrete.

Independent of the footing final failure mode, the start of the failure takes stress cracks form in the concrete for low loads.

The objective of this research work was to study the behavior of concentrically loaded isolated footings in front of the initial failure due to cracking, by measuring the stress cracking load in the concrete.

\section{Material and Methods}

\subsection{Calculation of Cracking Moment $\left(\mathrm{M}_{\mathrm{cr}}\right)$}

Cracking moment $(\mathrm{Mcr})$ was calculated with the flexure eq. $(1)^{5}$, according to the following expression:

$$
M_{c r}=\frac{f_{r} I_{g}}{y_{t}}
$$

Where $f r$ is the concrete rupture modulus, and $y_{t}$ the distance from the centroidal axis to its extreme fiber with tension $(\mathrm{H} / 2)$, and $I g$ is the inertia moment of the cross section with respect to the neutral axis $\left(\mathrm{BH}^{3} / 12\right)$.

\subsection{Concrete Modulus of Rupture ( $f r$ )}

Values as low as $0.33 \sqrt{f_{c}^{\prime}} \mathrm{Mpa}^{6}$ have been reported for $f r$ as well as high as $1.055 \sqrt{f_{c}^{\prime}} \mathrm{Mpa}^{\mathrm{z}}$. ACI $318-14$ Code establishes that $f r$ can be taken as $0.62 \lambda \sqrt{f^{\prime}}$, with $\lambda=1.0$ for the case of normal weight concrete ${ }^{5}$. The last value was adopted in this research to determine the theoretical cracking moment of the section.

\subsection{Flexing Moment $\left(M_{a p l}\right)$}

The moment acting in the critical section (Mapl) for isolated square footings loaded concentrically was calculated with eq. (2):

$$
M_{a p l}=\frac{\sigma_{n} B(B-a)^{2}}{8}
$$

Where $\sigma_{n}$, is the net soil contact pressure generated by the column load, $a$ is the column dimension and $B$ is the footing dimension. According to $\frac{8}{}$, the insulated footings consist of cantilevers protruding from the column in both directions, subject to the ground upward pressure causing stresses in the lower area of the footing.

\subsection{Load Frame}

Experimental tests were carried out on the University of

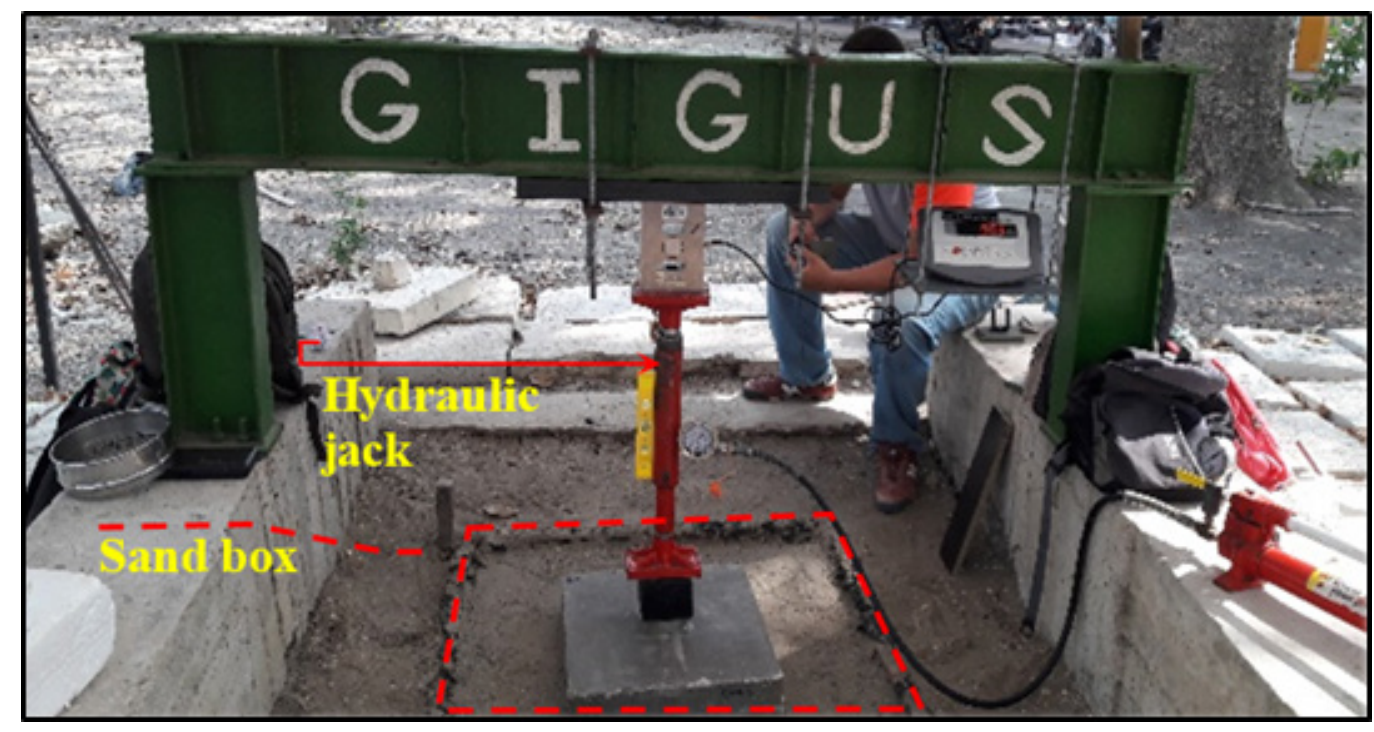

Figure 1. Rigid frame for experiment. 
Sucre campus by means of a loading frame (Figure 1) with a capacity of up to $200 \mathrm{kN}$. Vertical load was transmitted to the footing using a hydraulic jack and, a cell with a $100 \mathrm{kN}$ capacity was used to measure the force exerted. Nonetheless, footings were tested up to $95 \mathrm{kN}$.

Footings rested on a granular material filling, $1.5 \mathrm{~m}$ thick, inside a box arranged under the load frame. The granular filling material was subject to sieving, moisture content, unit weight, direct cutting and proctor tests; according to standard methods.

\subsection{Tested Elements}

The research was carried out on a group of 30 isolated square concrete footings, $450 \mathrm{~mm}$ on each side and reinforced with bars 6.3 in $\mathrm{mm}$ diameter (Figure 2). Six footing groups were analyzed following the specifications in the ACI 318-14 code $^{5}$.

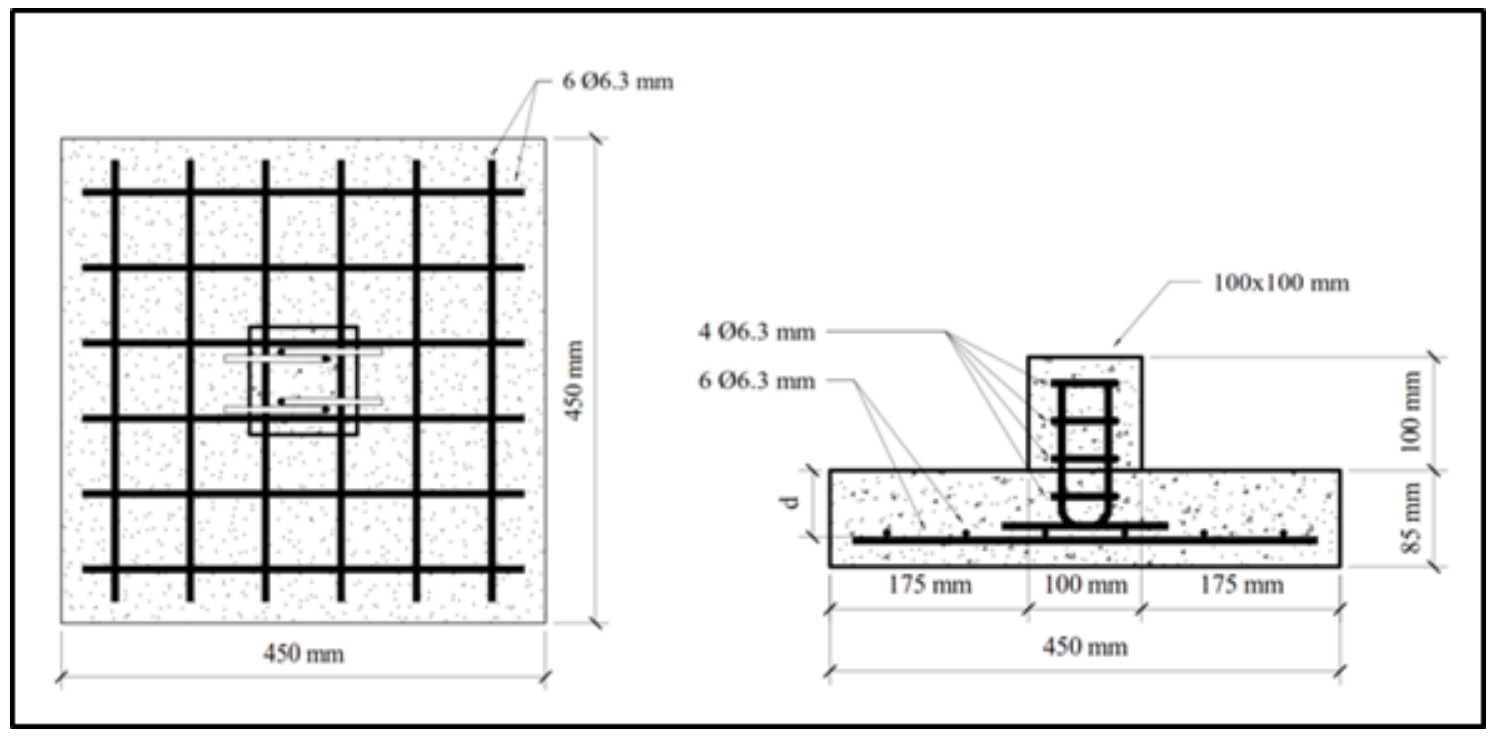

Figure 2. Dimensions and reinforcement of footings ZG1 and ZG2.

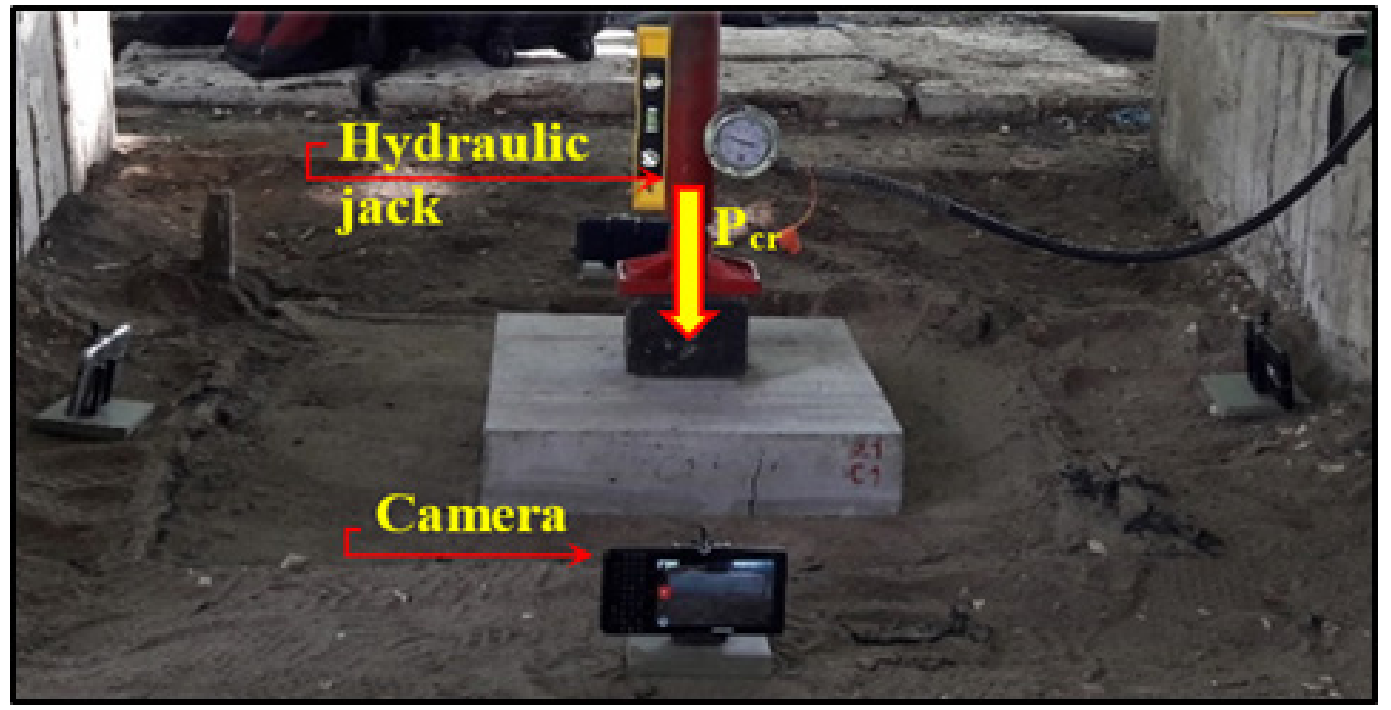

Figure 3. Footing subject to axial loads. 
Thicknesses $(\mathrm{H})$ and amounts of steel $(\rho)$ were determined to avoid occurrence of another type of failure. Load was transmitted to the footings by means of a square pedestal, $100 \mathrm{~mm}$ each side. Dimensions of each group corresponded to the capacity of the available measuring equipment $(100 \mathrm{kN})$. For the footings construction,

Table 1. Characteristics of tested footings

\begin{tabular}{|c|c|c|c|c|}
\hline $\begin{array}{c}\text { Footing } \\
\text { Designation }\end{array}$ & $\begin{array}{c}\text { Footing Depth } \\
\text { H (mm) }\end{array}$ & $\begin{array}{l}\text { Reinforcement } \\
\text { ratio } \rho(\%)\end{array}$ & $\begin{array}{c}\text { Concrete } \\
\text { Strength (MPa) }\end{array}$ & $\begin{array}{l}\text { Cracking Moment } \\
\text { Theoretical (kN-m) }\end{array}$ \\
\hline ZG1-1 & \multirow{10}{*}{85} & \multirow{10}{*}{0.8312} & \multirow{5}{*}{23.48} & \multirow{5}{*}{1.628} \\
\hline ZG1-2 & & & & \\
\hline ZG1-3 & & & & \\
\hline ZG1-4 & & & & \\
\hline ZG1-5 & & & & \\
\hline ZG2-1 & & & \multirow{5}{*}{21.88} & \multirow{5}{*}{1.572} \\
\hline ZG2-2 & & & & \\
\hline ZG2-3 & & & & \\
\hline ZG2-4 & & & & \\
\hline ZG2-5 & & & & \\
\hline ZG3-1 & \multirow{10}{*}{70} & \multirow{5}{*}{0.4618} & \multirow{5}{*}{24.00} & \multirow{5}{*}{1.116} \\
\hline ZG3-2 & & & & \\
\hline ZG3-3 & & & & \\
\hline ZG3-4 & & & & \\
\hline ZG3-5 & & & & \\
\hline ZG4-1 & & \multirow{5}{*}{0.7926} & \multirow{5}{*}{25.34} & \multirow{5}{*}{1.147} \\
\hline ZG4-2 & & & & \\
\hline ZG4-3 & & & & \\
\hline ZG4-4 & & & & \\
\hline ZG4-5 & & & & \\
\hline
\end{tabular}


Table 1 Continued

\begin{tabular}{|c|c|c|c|c|}
\hline ZG5-1 & \multirow{10}{*}{80} & \multirow{5}{*}{0.645} & \multirow{5}{*}{27.34} & \multirow{5}{*}{1.556} \\
\hline ZG5-2 & & & & \\
\hline ZG5-3 & & & & \\
\hline ZG5-4 & & & & \\
\hline ZG5-5 & & & & \\
\hline ZG6-1 & & \multirow{5}{*}{1.1083} & \multirow{5}{*}{24.16} & \multirow{5}{*}{1.463} \\
\hline ZG6-2 & & & & \\
\hline ZG6-3 & & & & \\
\hline ZG6-4 & & & & \\
\hline ZG6-5 & & & & \\
\hline
\end{tabular}

standard Portland cement concrete was used, with compression resistance determined at the test time.

From each footing group, 5 elements were tested. Load was gradually applied on the column (Figure 3). A film record was made of the sequence of the cracks appearance with a video camera, in each face of the footing.

Outlines the characteristics of each tested element and shows the theoretical cracking moment values $(\mathrm{Mcr})$ expected from eq. (1) (Table 1).

\section{Results and Discussion}

Tests results carried out on the support floor are shown in Table 2.
A final loading capacity of - $1024.8 \mathrm{kNm}^{-2}$ was obtained from the physical and mechanical properties of the employed granular filling; using Terzaghi's theor $y^{9}$ 2.2 safety factors was used, allowing guaranteeing that the filling would not fail due to cutting resistance. On the other hand, sand density does not affect distribution of pressure, i.e., the pressure exerted is possible to be considered as uniform with sufficient safety ${ }^{10}$.

Figure 4 shows the typical stress cracking pattern in concrete found in failed footings. In all cases, the first crack was positioned very close to the face of the column, validating the location of the critical section provided in the $\operatorname{code}^{5}$.

Table 2. Granular soil properties

\begin{tabular}{|c|c|c|c|c|c|}
\hline Soil Type & $\mathbf{W}(\%)$ & $\gamma_{\mathbf{d}}\left(\mathbf{k N} / \mathbf{m}^{3}\right)$ & $\phi^{\circ}$ & $\gamma_{\text {dmáx }}\left(\mathbf{k N} / \mathbf{m}^{3}\right)$ & $\mathbf{W}_{\text {opt }}(\%)$ \\
\hline Sand & 7.9 & 17.5 & 45 & 19.2 & 10 \\
\hline
\end{tabular}




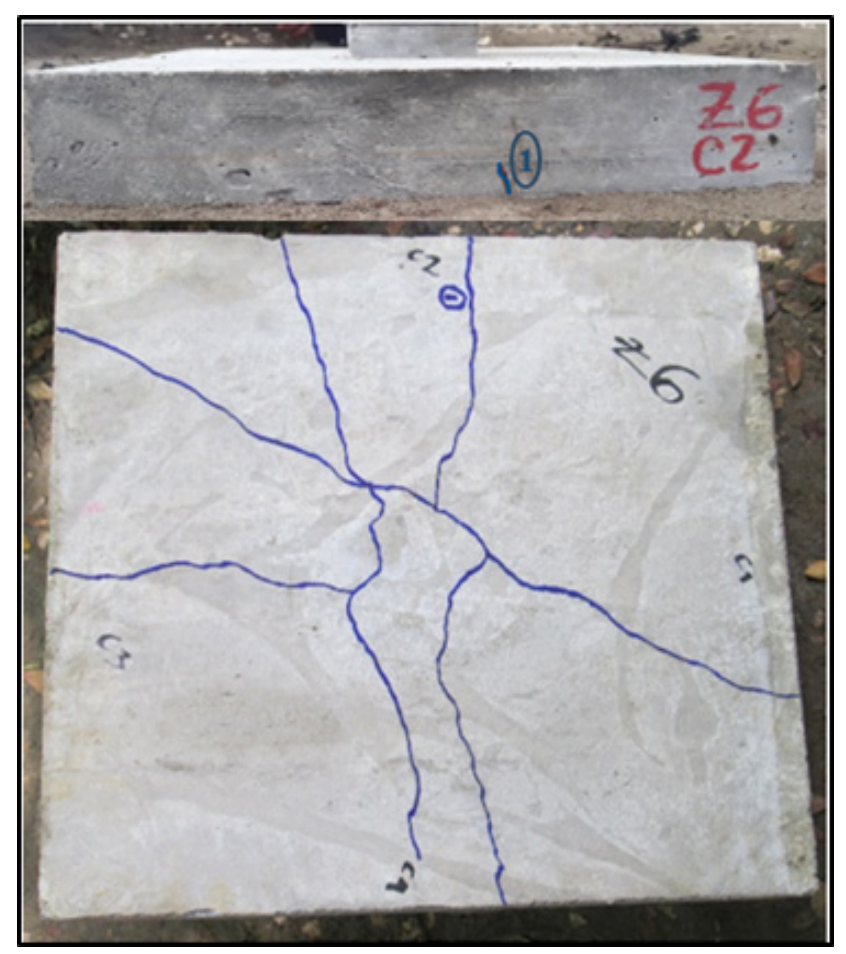

Figure 4. Stress cracking in concrete (ZG6-1).
After finding the experimental cracking load, the experimental flexural strength (Mapl) was determined in the critical section, from eq. (2). Table 3 shows the comparative results between the theoretical and experimental moments found for the failed footings.

Average relationship between the experimental and theoretical resistance was greater than 1.0 , indicating that the specification code can be considered conservative since it underestimates the resistance. A ratio between the resistors less than 1.0 indicates that the specification will be overestimated.

After verifying general compliance of the three independence hypotheses, normality and data homogeneity, a first ANOVA analysis was performed on 10 groups of footings with the same size and reinforcement characteristics (ZG1 with ZG2), to determine if their respective moments (Experimental and Theatrical) were significantly the same or different. Table 4 shows the results.

A 0.2194 P-value was obtained, higher than 0.05 , indicating that there is no statistically significant difference

Table 3. Moment of experimental cracking of the tested elements

\begin{tabular}{ccccc}
\hline $\begin{array}{c}\text { Footing } \\
\text { Designation }\end{array}$ & $\begin{array}{c}\text { Cracking Load } \\
\mathbf{P}_{\text {cr }}(\mathbf{k N})\end{array}$ & $\begin{array}{c}\mathbf{M}_{\text {apl }} \text { Experi- } \\
\text { mental }\end{array}$ & (Mean) \\
\hline ZG1-1 & 47.93 & 1.63 & 1.00 & \\
ZG1-2 & 45.11 & 1.53 & 0.94 & 1.03 \\
ZG1-3 & 56.60 & 1.93 & 1.18 & \\
ZG1-4 & 46.68 & 1.59 & 0.98 & \\
ZG1-5 & 50.10 & 1.70 & 1.05 & \\
\hline ZG2-1 & 47.58 & 1.62 & 1.03 & \\
ZG2-2 & 53.78 & 1.83 & 1.16 & \\
ZG2-3 & 56.15 & 1.91 & 1.22 & \\
ZG2-4 & 36.13 & 1.23 & 0.78 & \\
ZG2-5 & 56.21 & 1.91 & 1.22 & \\
\hline
\end{tabular}




\section{Table 3 Continued}

\begin{tabular}{|c|c|c|c|c|}
\hline ZG3-1 & 36.40 & 1.24 & 1.11 & \multirow{5}{*}{1.15} \\
\hline ZG3-2 & 55.84 & 1.90 & 1.70 & \\
\hline ZG3-3 & 25.82 & 0.88 & 0.79 & \\
\hline ZG3-4 & 38.04 & 1.29 & 1.16 & \\
\hline ZG3-5 & 32.50 & 1.11 & 0.99 & \\
\hline ZG4-1 & 56.50 & 1.92 & 1.68 & \multirow{5}{*}{1.31} \\
\hline ZG4-2 & 35.80 & 1.22 & 1.06 & \\
\hline ZG4-3 & 31.70 & 1.08 & 0.94 & \\
\hline ZG4-4 & 54.40 & 1.85 & 1.61 & \\
\hline ZG4-5 & 43.20 & 1.47 & 1.28 & \\
\hline ZG5-1 & 60.19 & 2.05 & 1.32 & \multirow{5}{*}{1.15} \\
\hline ZG5-2 & 60.59 & 2.06 & 1.32 & \\
\hline ZG5-3 & 41.13 & 1.40 & 0.90 & \\
\hline ZG5-4 & 45.30 & 1.54 & 0.99 & \\
\hline ZG5-5 & 56.26 & 1.91 & 1.23 & \\
\hline ZG6-1 & 68.80 & 2.34 & 1.60 & \multirow{5}{*}{1.55} \\
\hline ZG6-2 & 58.18 & 1.98 & 1.35 & \\
\hline ZG6-3 & 65.56 & 2.23 & 1.53 & \\
\hline ZG6-4 & 64.25 & 2.19 & 1.49 & \\
\hline ZG6-5 & 76.18 & 2.59 & 1.77 & \\
\hline
\end{tabular}

between the means of the experimental and theoretical cracking moments, with a $95.0 \%$ confidence level. Even though, in each footing group there is a difference between the values of compressive strength of concrete, it did not generate a considerable effect on the expected values of the experimental cracking moment.

Nonetheless, when calculating the ANOVA to groups of 10 footings with same size characteristics but different reinforcement amounts (ZG3 with ZG4 and ZG5 with ZG6), P-values of 0.0387 and 0.0002 respectively were obtained, being less than 0.05 . These results are shown in Table 5 and 6.

According to the above, there are statistically significant differences between means of moments of experimental and theoretical cracking, of footings ZG3 and ZG4, and footings ZG5 and ZG6. These results 
Table 4. ANOVA of experimental and theoretical cracking moment for ZG1 and ZG2

\begin{tabular}{|c|c|c|c|c|c|}
\hline Source & Sum of Squares & Gl & Mean Square & Ratio-F & Value-P \\
\hline Among Groups & 0.0393385 & 1 & 0.0393385 & 1.62 & 0.2194 \\
\hline Intra-groups & 0.4373860 & 18 & 0.0242992 & & \\
\hline Total (Correlation) & 0.4767250 & 19 & & & \\
\hline
\end{tabular}

Table 5. ANOVA of experimental and theoretical cracking moment for ZG3 and ZG4

\begin{tabular}{|c|c|c|c|c|c|}
\hline Source & Sum of Squares & Gl & Mean Square & Ratio-F & Value-P \\
\hline Among groups & 0.349537 & 1 & 0.349537 & 4.97 & 0.0387 \\
\hline Intra-groups & 1.26526 & 18 & 0.0702924 & & \\
\hline Total (Correlation) & 1.61480 & 19 & & & \\
\hline
\end{tabular}

Table 6. ANOVA of experimental and theoretical cracking moment for ZG5 and ZG6

\begin{tabular}{|c|c|c|c|c|c|}
\hline Source & Sum of Squares & Gl & Mean Square & Ratio-F & Value-P \\
\hline Among groups & 1.35200 & 1 & 1.352 & 21.12 & 0.0002 \\
\hline Intra-gruops & 1.15225 & 18 & 0.0640137 & & \\
\hline Total (Correlation) & 2.50425 & 19 & & & \\
\hline
\end{tabular}

allow establishing that there is a relationship between the expected cracking moment and reinforcement amount. For the tested amounts, the mean of moments of experimental cracking exceeded the mean of the theoretical; and the difference increased as the footing had greater amount. However, the study results are valid only for the characteristics of the granular filling used. Effects of the size and scale of the reduced model of footings have not been researched. Therefore, although results correspond to what is specified in the ACI 318-14 Code, it is necessary to verify them before relating them with actual size footings.

\section{Conclusions}

Based on the results of the experimental research of concentrically loaded footings, supported by granular filling, the following conclusions can be reached: 
- Stress cracking pattern in the concrete ratified the provisions of the regulations for the tested elements, regarding theoretical section location for the flexure design of reinforced concrete footings,

- For the granular filling used, it is confirmed that it is safe to consider a uniform contact pressure for calculating the cracking load of concentrically loaded isolated footings,

- Mean of the experimental cracking moment, always exceeded the expected value according to ACI 318-14 Code. The value recommended by the code for the calculation of rupture module was safe for the tested footings, and

- Cracking moment not only depends on the section size and the concrete compressive strength, it is also affected by reinforcement amount. The greater the reinforcement amount, the greater the difference between experimental and theoretical cracking moments.

Finallly, number of failed footings and tests on the same floor type, represent limitations when proposing general conclusions. Therefore, it is necessary to deepen in more detailed studiesto establish influence of steel amount in the magnitude of the cracking moment of isolated footings.

\section{Acknowledgements}

The author R.G. Hernández thanks Kendrys Cantillo and Santiago Velasquez, Civil Engineering students from
University of Sucre for their valuable contribution provided on this project.

\section{References}

1. George F, Limbrunner A, Aghayere O. Reinforced Concrete Design. 8th ed. Pearson Education, Inc: New York; 2014. p. $1-312$.

2. Subramanian N. Design of Reinforced Concrete Structures. Oxford University Press: New Delhi, India; 2013.

3. Thornburn PH. Fundation Engineering. 2nd ed. John Wiley and Sons, Inc: New Jersey; 1974.

4. Calavera J. Cálculo de Estructuras de Cimentación. 4th ed. Intemac Ediciones: Madrid, Espa-a; 2000.

5. American Concrete Institute. Building Code Requirements for Structural Concrete, ACI 318-14. American Concrete Institute: Washington, D.C.; 2014. p. 1-524.

6. Hmed M, Dad Khan MK, Wamiq M. Effect of concrete cracking on the lateral response of RCC buildings, Asian Journal of Civil Engineering (Building and Housing). 2008; 9(1):25-34.

7. Ahmed M, Hadi KME, Hasan MA, Mallick J, Ahmed A. Evaluating the co-relationship between concrete flexural tensile strength and compressive strength, International Journal of Structural Engineering. 2014; 5(2):115-31. https://doi.org/10.1504/IJSTRUCTE.2014.060902.

8. Crespo-Villalaz C. Mecánica de suelos y Cimentaciones. 4th ed. Limusa Editores: México D.F.; 1998. p. 1-652.

9. Das BM. Principles of Foundation Engineering. 8th ed. Cengage Learning; 2016. p. 1-896.

10. Hegger J, Sherif AG, Ricker M. Experimental Investigations on Punching Behavior of Reinforced Concrete Footings, ACI Structural Journal. 2006; 103(4):604-13. 